\title{
New species of Leporinus (Characiformes: Anostomidae) from the highlands of the Guiana Shield in Venezuela
}

\author{
José L. O. Birindelli ${ }^{1}$, Heraldo A. Britski² and Francisco Provenzano ${ }^{3,4}$
}

A new species of Leporinus is described using morphological data and compared to all other species of the family. Specimens were illustrated using digital photograph, measured using digital calipers, and had teeth, scales, and fin rays counted under a stereomicroscope. The new species is distinguished from all other Anostomidae, except Anostomus anostomus, A. brevior, A. ternetzi, Hypomasticus despaxi, Leporinus arcus, and L. striatus, by having four dark longitudinal stripes on body. The new species is distinguished from aforementioned species by having terminal mouth with four teeth on the premaxilla, 12 series of scales around caudal peduncle, and 34 to 36 scales in the lateral line. The new species is remarkably similar to Leporinus arcus, which occurs on the opposite side of Guyana Shield highlands. The new species and $L$. arcus are possibly closely related to Leporinus gomesi, L. granti, L. lebaili, L. melanostictus, L. nijsseni, and L. santosi.

Keywords: Anostomoidea, Phylogeny, South America, Systematics, Taxonomy.

Uma espécie nova de Leporinus é descrita usando dados morfológicos e comparações entre todas as espécies da família. Exemplares foram ilustrados com fotografia digital, medidos com paquímetro digital e seus dentes, escamas e raios das nadadeiras foram contados sob estereomicroscópio. A espécie nova distingue-se dos demais Anostomidae, exceto Anostomus anostomus, A. brevior, A. ternetzi, Hypomasticus despaxi, Leporinus arcus e L. striatus, por apresentar quatro faixas longitudinais no corpo. A nova espécie distingue-se das espécies mencionadas por ter boca terminal com quatro dentes no osso pré-maxilar, 12 séries de escamas ao redor do pedúnculo caudal e 34 a 36 escamas na linha lateral. A espécie nova é particularmente similar à Leporinus arcus, que ocorre no lado oposto das terras altas do Escudo da Guiana. A espécie nova e L. arcus, possivelmente, são relacionadas proximamente à Leporinus gomesi, L. granti, L. lebaili, L. melanostictus, L. nijsseni e L. santosi.

Palavras-chave: América do Sul, Anostomoidea, Filogenia, Sistemática, Taxonomia.

\section{Introduction}

Anostomidae is one of the most diverse families of Characiformes (Reis et al., 2003) and the number of known species is still increasing rapidly as field expeditions are carried out and museum's old collections are revisited (Birindelli, Britski, 2009; Britski et al., 2012). The family currently includes 15 genera (Sidlauskas, Vari, 2008; Ramirez et al., 2017), with species unevenly distributed among them. Leporinus Agassiz, 1829 is by far the richest genus with approximately 90 valid species (Burns et al., 2017). The phylogenetic relationships within Anostomidae are still poorly understood. Nevertheless, no doubts remains that Leporinus is not monophyletic, and should be split into several groups as studies advance (Sidlauskas, Vari, 2008; Ramirez et al. 2016).

During visits to fish collections in the United States and Venezuela, a new species of Leporinus was discovered. The species inhabits highlands of the Guyana Shield in Venezuela, where characteristic table-mountain formations (the Tepuis) emerge from a plain called the Gran Savana (Great Savanna). Here, the new species is described using morphological data and compared to all other species of the family. Comments on the new species phylogenetic relationships and biogeographical history are provided.

\footnotetext{
${ }^{1}$ Museu de Zoologia, Departamento de Biologia Animal e Vegetal, Universidade Estadual de Londrina, Rodovia Celso Garcia Cid km 380, Caixa Postal 10011, 86057-970 Londrina, PR, Brazil. josebirindelli@yahoo.com, Dhttps://orcid.org/0000-0001-9646-9636 (corresponding author)

${ }^{2}$ Museu de Zoologia da Universidade de São Paulo, Av. Nazaré, 481, Ipiranga, Caixa Postal 42494, 04218-970 São Paulo, SP, Brazil. heraldo@usp.br, Dhttps://orcid.org/0000-0002-5593-9651

${ }^{3}$ Universidad Central de Venezuela, Facultad de Ciencias, Instituto de Zoología y Ecología Tropical, Apartado 47058 Caracas 1041-A, Distrito Capital, Venezuela. fprovenz@gmail.com, Dhttps://orcid.org/0000-0003-3296-2311

${ }^{4}$ Departamento de Biología, Facultad de Ciencias, Escuela Politécnica Nacional, Quito, Ecuador.
} 


\section{Material and Methods}

Counts and measurements were taken according to Britski, Garavello (1978) and Winterbottom (1980). Meristic data are given in the description, with the frequency of each count provided in parentheses after the respective count, and an asterisk indicating counts of the holotype. Lateral line scale counts included the pored scales extending onto base of the median caudal-fin rays. The upper transversal series of scales is represented by the number of rows of scales between the lateral line and the dorsal-fin origin (counting neither the scale on the middorsal series immediately anterior to the dorsal-fin origin, nor the small scale at the base of the anteriormost dorsal-fin ray); this procedure always eliminates the very confusing count of a half scale in this series. A half scale in the scale series between the lateral line and pelvic-fin origin is only counted when the base of pelvic-fin first ray faces anteriorly the middle of the scale immediately in front of it. All examined material is alcohol preserved, except when indicated by cs, for specimens cleared and double stained following protocol of Taylor, van Dyke (1985). Institutional abbreviations follow Sabaj (2016).

\section{Results}

\section{Leporinus tepui, new species}

urn:1sid:zoobank.org:act:BAA0E2DB-3FEB-4421-BB8C0E78A7FDF81F

Fig. 1
Leporinus arcus.-Chernoff, Machado-Allison, Riseng, Mointambault, 2003: 70 (upper Caura River, AquaRAP report).

Holotype. FMNH 45711, 143.7 mm SL, Venezuela, Bolívar, río Orinoco basin, Chimantá-tepuí, c. $5^{\circ} 18^{\prime} \mathrm{N} 62^{\circ} 10^{`} \mathrm{~W}, 27$ Mar 1953, J. Steyermark.

Paratypes. All from Venezuela, Bolívar, río Orinoco basin. MZUEL 21000, 1, 42.8 mm SL; MZUSP 124855, 1, 41.3 mm SL. FMNH 109898, 2, 41.0-69.6 mm SL, Raudal (rapids) in río Erebato and mouth of creek across river, río Caura drainage, 552’44”N 64²9’34”W, 27 Nov 2000, F. Provenzano, B. Chernoff, A. Rojas, A. Machado-Allison. FMNH 109899, 2, 37.6-45.6 mm SL, Rocks with grasses on side of island near Salto Para-Quyuna, río Eretabo, río Caura drainage, $6^{\circ} 18^{\prime} 56^{\prime \prime} \mathrm{N} 64^{\circ} 29^{\prime} 11^{\prime \prime} \mathrm{W}, 30$ Nov 2000, F. Provenzano, B. Chernoff, A. Rojas, A. Machado-Allison. FMNH 109900, 1, $40.9 \mathrm{~mm}$ SL, rocky beach above Salto Para-Quyuna Soodii, río Eretabo, río Caura drainage, $6^{\circ} 18^{\prime} 39^{\prime \prime} \mathrm{N}$ 64²9’2”W, 30 Nov 2000, F. Provenzano, B. Chernoff, A. Rojas, A. Machado-Allison. MBUCV 26643, 3, 30.1-32.8 mm SL, Salto Para, río Arriba, 17 Sep 1993, F. Provenzano, A. Machado, D. Machado, C. Marcano, C. Silvera, A. Rojas. MBUCV 20733, 4, 29.6-43.3 mm SL, Raudal Guaiquinima, 2h downstream from Camp Carapo, río Paragua, 19 Feb 1990, S. Ramirez, A. Machado. MBUCV 30202, 2, 33.5-45.2 mm SL, río Caura, isla at

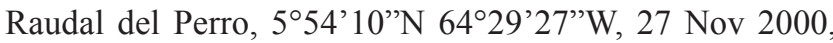
F. Provenzano, A. Machado, A. Rojas, B. Chernoff. UF 77784, 1, 45.5 mm SL, río Erebato, 24 Mar 1984, S. Reid, L. R. Franz.

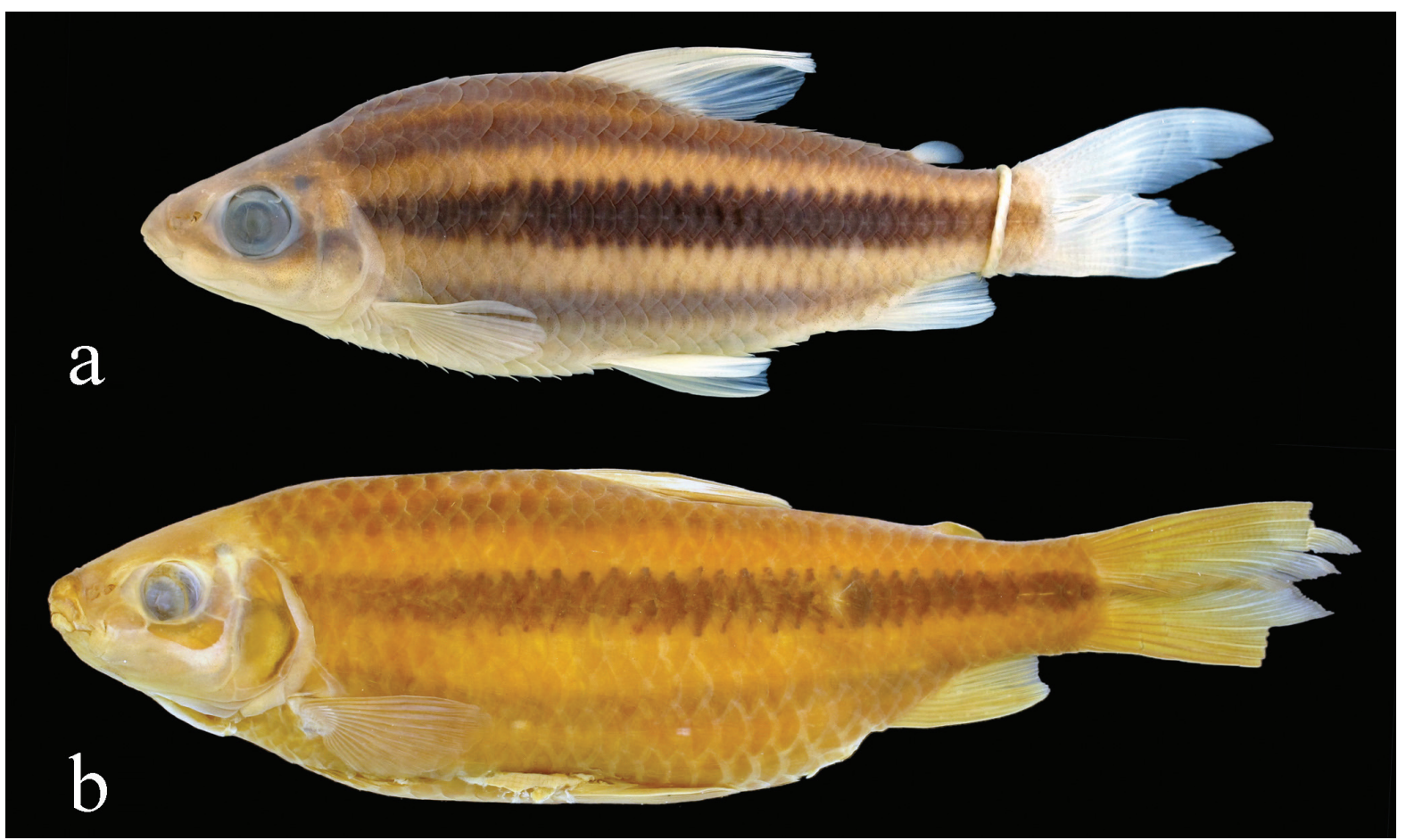

Fig. 1. Leporinus tepui, new species: (a) FMNH 109898, paratype, 69.6 mm SL; (b) FMNH 45711, holotype, 143.7 mm SL. 
Diagnosis. Leporinus tepui is distinguished from all other Anostomidae, except Anostomus anostomus (Linnaeus, 1758), A. brevior Géry, 1961, A. ternetzi Fernández-Yépez, 1949, Hypomasticus despaxi (Puyo, 1943), Leporinus arcus Eigenmann, 1912, and L. striatus Kner, 1858, for having four dark longitudinal stripes on body. The new species is distinguished from the species of Anostomus Scopoli, 1777 by having terminal mouth (vs. upturned) and 12 scale series around caudal peduncle (vs. 16); from Hypomasticus despaxi and Leporinus striatus by having four teeth on premaxilla ( $v s$. three), and 12 series of scales around caudal peduncle ( $v s$. 16); and from Leporinus arcus by having 12 series of scales around caudal peduncle (vs. 16) and 34 to 36 scales on lateral line (vs. 36 to 38$)$.

Description. Morphometric data is provided in Tab. 1. Small size, relative to congeners; largest examined specimen $143.7 \mathrm{~mm}$ SL. Head and body elongate and moderately compressed. Dorsal profile gently convex from snout tip to dorsal-fin origin, slightly convex along dorsal-fin base, more or less straight from end of dorsal-fin base to adiposefin origin, and slightly concave from adipose-fin origin to anteriormost dorsal caudal-fin procurrent ray. Ventral profile slightly to strongly concave from lower jaw to vertical through anterior margin of eye, straight to slightly concave from that point to vertical through posterior margin of opercle, convex from latter point to anal-fin origin, slightly convex along anal-fin base, and gently concave from analfin end to anteriormost ventral caudal-fin procurrent ray. Greatest body depth slightly anterior to dorsal-fin origin.

Mouth terminal, its cleft longitudinally aligned with ventral margin of iris. Snout rounded, anteriorly blunt. Premaxillary with four*(27) incisiform teeth gently decreasing in size from symphyseal tooth. Dentary with four*(23) or five(4) incisiform teeth also gently decreasing in size laterally. Teeth with two or three rudimentary cusps in specimens of $50 \mathrm{~mm}$ SL or less.
Scale cycloid. Lateral line complete with 34(2), 35*(20), or 36(5) perforated scales, extending from supracleithrum to base of median caudal-fin rays. Horizontal scale rows between dorsal-fin origin and lateral line four*(22) or five(5). Horizontal scale rows between lateral line and pelvic-fin origin four*(27). Horizontal scale rows around caudal peduncle $12 *(27)$. Predorsal scales from dorsal-fin origin to tip of supraoccipital spine $9(7), 10^{*}(11)$ or $11(8)$.

Dorsal-fin rays ii, $10 *(27)$. Dorsal-fin origin slightly anterior to middle of standard length and to vertical through pelvic-fin origin; its distal margin gently concave. Adipose fin small, teardrop shaped, its origin approximately at vertical through base of last anal-fin ray. Pectoral-fin rays $\mathrm{i}, 14^{*}(9), \mathrm{i}, 15(12)$ or i,16(3); fin tip extending more than half the distance between origins of pectoral and pelvic fins; its distal margin slightly convex. Pelvic-fin rays i, $8^{*}(26)$; its distal margin slightly convex. Anal-fin rays ii, $8 *(26)$; fin origin approximately at vertical through third scale anterior to adipose-fin origin, when adpressed fin does not reach base of caudal-fin rays; its distal margin slightly concave. Principal caudal-fin rays $i, 8,9, i^{*}(26)$. Caudal fin forked, lobes rounded, upper lobe slightly longer than lower lobe.

Coloration. Ground color of head and body light brown and countershaded. Body with four dark longitudinal stripes: dorsalmost stripe almost middorsal, from head to dorsal-fin end, and one scale in depth; second stripe from head above opercle to base of caudal-fin upper lobe, one scale deep; third stripe midlateral, more conspicuous than other stripes, from dorsalmost portion of gill opening to base of median caudalfin rays, two scale depth; fourth stripe from pectoral insertion to anal-fin base, one scale deep. Head with one dark spot immediately posterior to sixth infraorbital, and a dark oblique stripe from top of snout to ventral margin of eye, and extending posteriorly to ventral portion of opercle. Ventral surfaces of head and body pale to cream. All fins uniformly tan.

Tab. 1. Morphometric data for Leporinus tepui, new species, and L. arcus. $\mathrm{SD}=$ Standand Deviation; $\mathrm{n}=$ number of specimens.

\begin{tabular}{|c|c|c|c|c|c|c|c|c|c|c|}
\hline & \multicolumn{5}{|c|}{ Leporinus tepui, new species } & \multicolumn{5}{|c|}{ Leporinus arcus } \\
\hline & $\mathrm{n}$ & Mean & Range & SD & Holotype & $\mathrm{n}$ & Mean & Range & SD & Holotype \\
\hline Standard Length $(\mathrm{mm})$ & 27 & & $29.6-143.7$ & & 143.7 & 18 & & $36.4-308.5$ & & 189.8 \\
\hline \multicolumn{11}{|c|}{ Percentages of SL } \\
\hline Predorsal distance & 16 & 51.0 & $46.9-55.2$ & 2.13 & 47.7 & 10 & 48.3 & $46.4-52.3$ & 1.74 & 46.5 \\
\hline Dorsal-fin origin to adipose-fin origin & 8 & 38.5 & $37.5-39.9$ & 0.85 & 38.1 & 9 & 39.3 & $37.4-41.5$ & 1.45 & 39.8 \\
\hline Prepelvic distance & 16 & 53.8 & $50.6-60.1$ & 2.44 & 50.6 & 10 & 50.9 & $49.0-52.3$ & 1.03 & 49.0 \\
\hline Body depth & 16 & 31.3 & $25.0-33.5$ & 2.08 & 30.4 & 10 & 29.9 & $27.4-32.5$ & 1.44 & 27.4 \\
\hline Caudal peduncle length & 16 & 12.0 & $10.7-13.4$ & 0.67 & 10.9 & 10 & 10.9 & $10.2-11.9$ & 0.55 & 10.3 \\
\hline Caudal peduncle depth & 8 & 12.6 & $11.4-13.5$ & 0.71 & 13.4 & 9 & 12.6 & $9.4-14.6$ & 1.75 & 13.8 \\
\hline Anal-fin lobe length & 16 & 17.7 & $10.8-20.1$ & 2.15 & 16.3 & 10 & 15.8 & $14.6-18.0$ & 0.97 & 15.4 \\
\hline Head length & 16 & 29.3 & $24.7-31.8$ & 1.83 & 24.7 & 10 & 25.9 & $24.0-28.1$ & 1.52 & 24.0 \\
\hline \multicolumn{11}{|c|}{ Percentages of HL } \\
\hline Preopercle length & 8 & 77.2 & $75.0-82.3$ & 2.38 & 77.2 & 9 & 77.8 & $75.0-82.3$ & 2.42 & 75.0 \\
\hline Snout length & 16 & 38.1 & $33.6-42.9$ & 2.63 & 39.7 & 10 & 39.9 & $35.8-41.9$ & 1.89 & 40.0 \\
\hline Head depth & 8 & 82.7 & $78.8-88.2$ & 3.41 & 88.2 & 9 & 82.7 & $76.3-92.9$ & 4.56 & 84.2 \\
\hline Eye diameter & 16 & 30.9 & $23.1-35.4$ & 2.90 & 23.1 & 10 & 23.0 & $15.8-28.4$ & 4.48 & 22.2 \\
\hline Bony interorbital & 16 & 37.7 & $35.4-41.3$ & 1.93 & 37.5 & 10 & 41.2 & $36.8-47.9$ & 3.19 & 43.7 \\
\hline
\end{tabular}


Geographic distribution. Leporinus tepui is known from tributaries of the río Orinoco basin, in the highlands of the Guyana Shield in Venezuela (Fig. 2).

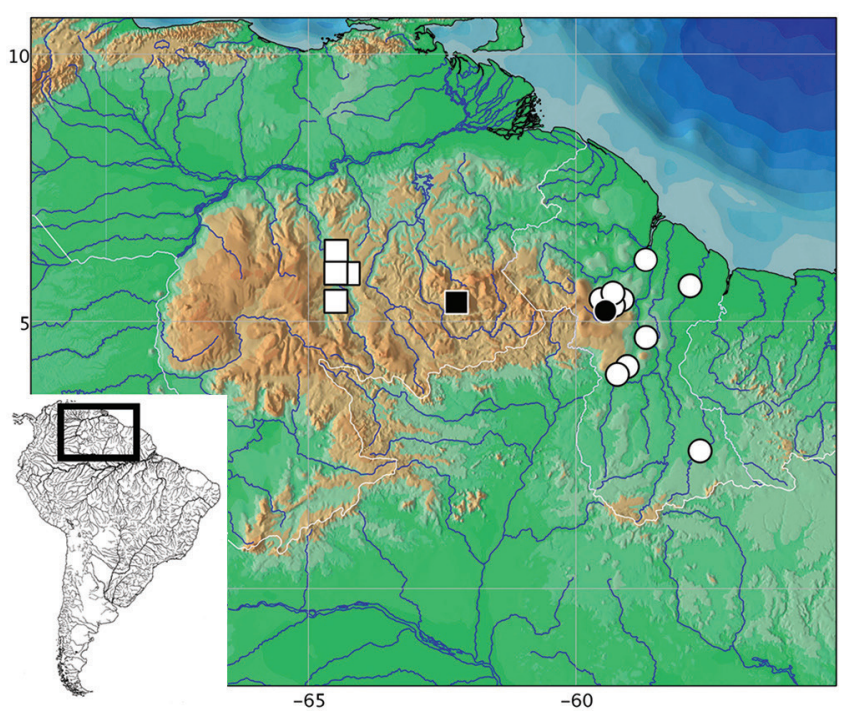

Fig. 2. Map of north portion of South America, showing the distribution of Leporinus tepui, new species (squares), and L. arcus (circles). Black symbols represent type localities.

Ecological notes. Specimens of Leporinus tepui were collected in fast flowing environments among specimens of L. granti, Moenkhausia spp., and other Characiformes (Chernoff et al., 2003).

Etymology. The species name comes from the type locality of the new species, a Tepui. The Tepuis are characteristic table-top mountains found in the Guiana Shield highlands. The word Tepui means "house of the gods" in the native tongue of the Pemon, the indigenous people that inhabit the Gran Savana in Venezuela. A noun in apposition.

Conservation status. The species is known only from few specimens collected in a remote, largely subsampled area of Venezuela. However, the apparently broad distribution of the species (at least $20.000 \mathrm{~km}^{2}$, considering a polygon uniting all known sites), and the fact that the area is relatively well preserved, leads us to consider it as a Least Concern species (LC, following IUCN criteria, IUCN, 2017).

\section{Discussion}

Most species of Anostomidae have four teeth on the dentary and premaxillary bones. Nevertheless, some species have reduction of that number, and possess three teeth on the premaxilla and/or on dentary. The only exception is Gnathodolus bidens Myers, 1927, that presents a single dentary tooth (Myers, 1927). Hence, this is a very informative diagnostic character for the group and the species can be classified according to their dental formulae (3/3, 3/4, 4/3 and 4/4) (Britski, Birindelli, 2008). Variation in dental formulae is rare among species of Anostomidae, usually present in only one side of the specimens, and usually explained as an anomaly. However, the presence of five dentary teeth in approximately one-fifth of the specimens of Leporinus tepui is unexpected and perhaps better understood as a polymorphism. A survey of the same feature in other Anostomidae revealed that some specimens of Leporinus arcus (three of four examined specimens), L. gomesi Garavello, Santos, 1981 (four of 27), L. granti Eigenmann, 1912 (eight of 24), and $L$. nijsseni Garavello, 1990 (two of 11) also have five dentary teeth (at least on one side of the jaw). This feature is herein interpreted as a polymorphism present in these species.

Leporinus tepui is remarkably similar to L. arcus (Fig. 3, Tab. 1) for having four longitudinal stripes on body, including a distinctly deeper midlateral stripe, a dark spot immediately posterior to sixth infraorbital, and four (eventually five) teeth on dentary. Nevertheless, the two species are easily distinguished based on the number of scale rows around the caudal peduncle. The similarity and the disjunct distribution on opposite sides of Guyana Shield highlands indicate a sister-group relationship between the two species. Similar distribution patterns were reported for other fishes, including Lithoxus Eigenmann, 1910 and Exaslithoxus Isbrücker, Nijssen, 1979, among others (Lujan, 2008). Approximately 65 Mya, the Guyana Shield southern slope was drained by a single river, the Proto-Berbice, that extended from Venezuela through the north Rupununi and outflow into the Atlantic via where now is the mouth of the Berbice River (McConnell et al., 1969; Lujan, 2008). The uplift of the Guyana highlands might have broken the ProtoBerbice basin into independent rivers that flow West to the Orinoco and East to the Rupununi River.

Leporinus tepui and L. arcus are possibly closely related to Leporinus gomesi, L. granti, L. lebaili, L. melanostictus Norman, 1926, L. nijsseni, and L. santosi Britski, Birindelli, 2013. This species group was previously discussed in Britski, Birindelli (2013) and it is diagnosed by having small dark spots on anterior portion of scales of the lateral body surface, formed by epidermal pigment (red in live specimens, as in Fig. 3, spots faded in alcohol preserved specimens), terminal mouth with four teeth on premaxillary bone and four (eventually five) on dentary bone, relatively few scales in the lateral line (usually less than 36), and a dark spot immediately posterior to the sixth infraorbital. Leporinus gomesi was the only species of the group included in Sidlauskas, Vari (2008) phylogenetic analysis based on morphology, and it was recovered as sister group to all Anostomidae, except Leporellus Lütken, 1875 and Hypomasticus Borodin, 1929. Based on molecular data (COI, Cytb, Mhy6, RAG1, and RAG2), Leporinus cf. granti (identified therein as Leporinus sp.) was recovered close to Hypomasticus, including H. mormyrops (Steindachner, 1875) (type species) and $H$. megalepis (Ramirez et al., 2016). Additional analyses are necessary to test the monophyly of the Leporinus granti species group, as herein proposed, as well as to test its phylogenetic position among Anostomidae. 


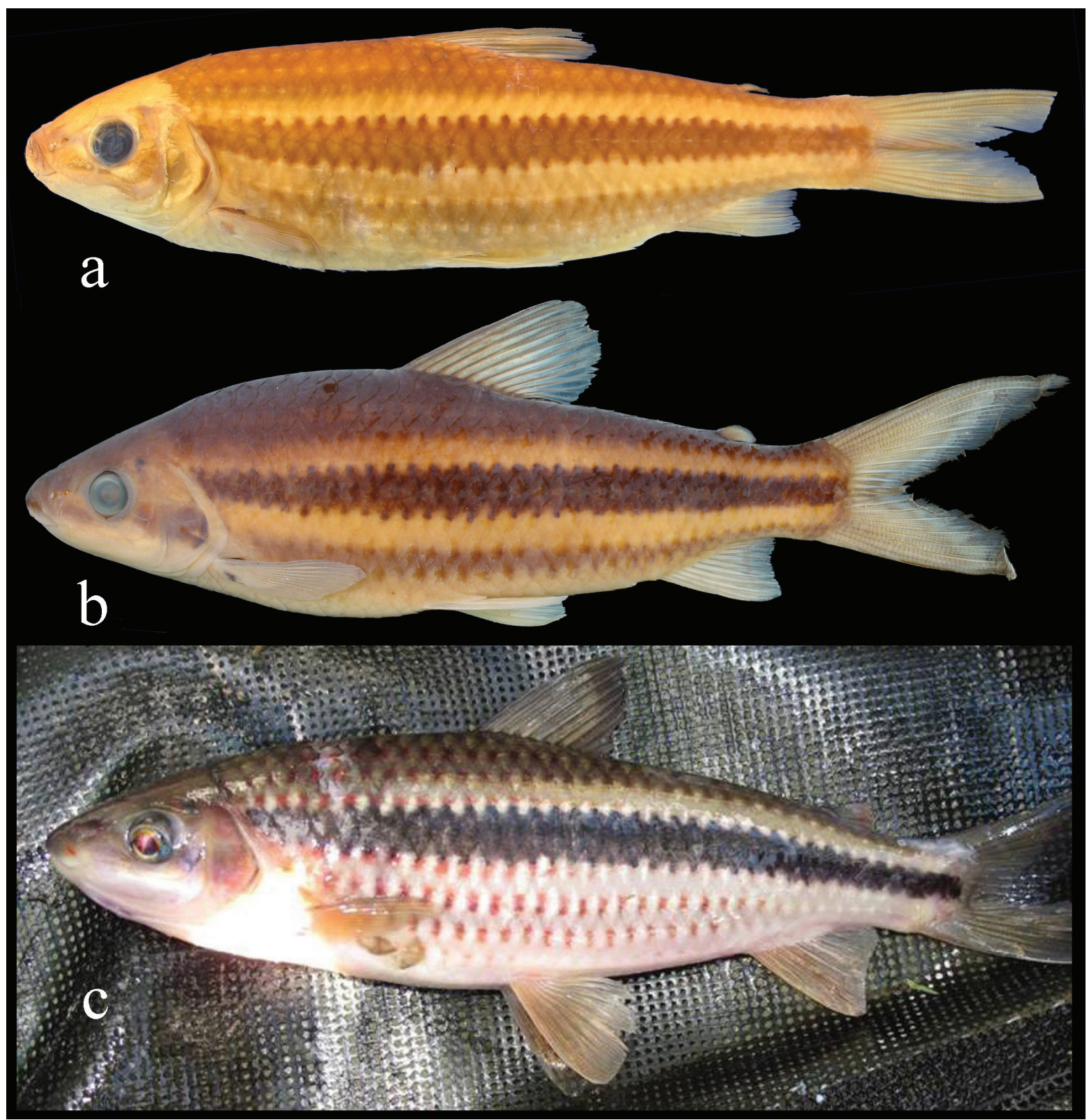

Fig. 3. Leporinus arcus: (a) FMNH 53366, holotype, 189.8 mm SL: (b) ANSP 175458, 143.0 mm SL, (c) MZUSP 108859, $219.3 \mathrm{~mm}$ SL (photographed live).

Comparative examined material. Anostomus anostomus. Guyana. Essequibo River Basin. ANSP 180303, 12, 32.4-106.9 mm SL. Anostomus brevior. Suriname. Marowjine River Basin. ANSP 189141, 4, 58.2-80.3 mm SL. Anostomus ternetzi. Venezuela. Orinoco River basin. ANSP 135762, $77.2 \mathrm{~mm}$ SL. Leporinus arcus. Guyana. Essequibo River basin. ANSP 175458, 1, 143.0 mm SL. ANSP 175459, 1, 64.2 mm SL. ANSP 175460, 1, 59.8 mm SL. ANSP 176695, 2, 127.1-147.0 mm SL. ANSP 176696, 2, 41.5-119.0 mm SL. ANSP 176697, 2, 50.5-103.4 mm SL. ANSP 176698, 2, 45.3-52.1 mm SL. ANSP 176699, 2, 49.7-61.5 mm SL. ANSP 176700, 2, 53.3-58.9 mm SL. ANSP 176701, 1, $52.26 \mathrm{~mm}$ SL. ANSP 176702, 1, $46.5 \mathrm{~mm}$ SL. ANSP 176703, 1, $42.7 \mathrm{~mm}$ SL. ANSP 176704, 1, $48.0 \mathrm{~mm}$ SL. ANSP 179647, 1, $48.9 \mathrm{~mm}$ SL. BMNH 1912.1.31.3, 1, 49.6 mm SL, paratype of Leporinus arcus
Eigenmann, 1912. BMNH 1934.9.12.301-302, 2, 198.6-207.9 mm SL. BMNH 1972.10.17.1477, 1, 245.0 mm SL. CAS 61865, 1, 48.6 mm SL. CAS 61866, 1, 36.4 mm SL. CAS 68167, 1, 81.4 mm SL. FMNH 53366, $189.8 \mathrm{~mm}$ SL, holotype of Leporinus arcus Eigenmann, 1912. FMNH 53795, 1, $308.5 \mathrm{~mm}$ SL paratype of Leporinus arcus Eigenmann, 1912. MZUSP 108859, 1, $219.3 \mathrm{~mm}$ SL. MZUSP 109146, 2, 189.4-206.2 mm SL. Berbice River basin. USNM 341895, 1, $70.1 \mathrm{~mm}$ SL. Correntyne River basin. FMNH 50165, 3, 75.8-93.3 mm SL. Leporinus lebaili. Suriname. Litania River Basin. ANSP 189011, 1, 65.1 mm SL. Suriname. Lawa River Basin. ANSP 189043, 2, 51.0-97.5 mm SL. French Guiana, Maroni River Basin, MNHN 98-1592, 2, 68.7-81.1 mm SL. See Birindelli, Britski (2013), Birindelli et al. (2013), and Britski, Birindell (2013) for additional comparative material. 


\section{Acknowledgments}

We are grateful to Oscar Shibatta (MZUEL), Fernando Dagosta (UFGD), Fernando Carvalho (UFMS) and an anonymous reviewer for comments and suggestions to the manuscript. For loan and exchanges of specimens and for their hospitality during visits to fish collections under their care, we thank John Lundberg, Mark Sabaj and Mariangeles Arce (ANSP), Dave Catania and Tomio Iwamoto (CAS), Caleb McMahan, Kevin Swagel, and Susan Mochel (FMNH), Richard Vari (USNM) (in memoriam), Ralf Britz, James Maclaine and Oliver Crimmen (BMNH), Larry Page (UF), Oscar León and Otto Castillo (MCNG). We also thank Flávio Lima (ZUEC) for providing the picture of a live specimen of Leporinus arcus. We thank Jorge Ramirez Malaver (UNMSM) for providing pictures and information on the specimens he used in his studies. Antonio Machado-Allison (UCV, WU) and Barry Chernoff (WU) organized the expeditions to Caura River, in 1993 and 2000, and supported the participation of FPR in both. Authors were financially supported by $\mathrm{CNPq}$ (HAB and JLOB, process 302872/2018-3), and FAPESP (JLOB, process 10/51250-9).

\section{References}

Birindelli JLO, Britski HA. New species of the genus Leporinus Agassiz (Characiformes: Anostomidae) from the rio Curuá, rio Xingu basin, Serra do Cachimbo, Brazil, with comments on Leporinus reticulatus. Neotrop Ichthyol. 2009; 7(1):1-9.

Birindelli JLO, Britski HA. Two new species of Leporinus (Characiformes: Anostomidae) from the Brazilian Amazon, and redescription of Leporinus striatus Kner, 1858. J Fish Biol 2013; 83(5):1-33.

Birindelli JLO, Peixoto LAW, Wosiacki WB, Britski HA. New Species of Hypomasticus Borodin, 1929 (Characiformes: Anostomidae) from tributaries of the lower rio Amazonas, Brazil. Copeia. 2013; 2013(3):464-69.

Britski HA, Birindelli JLO. Description of a new species of the genus Leporinus Spix (Characiformes: Anostomidae) from the rio Araguaia, Brazil, with comments on the taxonomy and distribution of $L$. parae and L. lacustris. Neotrop Ichthyol. 2008; 6(1):45-51.

Britski HA, Birindelli JLO. A new species of Leporinus Agassiz, 1829 (Characiformes: Anostomidae) from the rio Tocantins, Brazil. Neotrop Ichthyol. 2013; 11(1):25-32.

Britski HA, Birindelli JLO, Garavello JC. A new species of Leporinus Agassiz, 1829 from the upper rio Paraná basin (Characiformes, Anostomidae) with redescription of $L$. elongatus Valenciennes, 1850 and L. obtusidens (Valenciennes, 1837). Pap Avulsos Zool. 2012; 52(37):441-75.

Britski HA, Garavello JC. Sobre Leporinus octofasciatus Steindachner da bacia do Paraná (Pisces, Anostomidae). Pap Avulsos Zool. 1978; 31(16):237-50.
Burns MD, Chatfield M, Birindelli JLO, Sidlauskas BL. Systematic assessment of the Leporinus desmotes species complex, with a description of two new species. Neotrop Ichthyol. 2017; 15(2):e160166. Available from: http://dx.doi. org/10.1590/1982-0224-20160166

Chernoff B, Machado-Allison A, Riseng K, Montambault JR. A biological assessment of the aquatic ecosystems of the Caura River Basin, Bolívar State, Venezuela. RAP Bulletin of Biological Assessment 28. Washington, DC: Conservation International; 2003.

International Union for Conservation of Nature (IUCN). Standards and Petitions Subcommittee. Guidelines for using the IUCN Red List categories and criteria. Version 13 [Internet]. 2017 [updated $2017 \mathrm{Mar}$. Available from: http://cmsdocs. s3.amazonaws.com/RedListGuidelines.pdf

Lujan NK. Description of a new Lithoxus (Siluriformes: Loricariidae) from the Guayana Highlands with a discussion of Guiana Shield biogeography. Neotrop Ichthyol. 2008; 6(3):413-18.

McConnell RB, Masson Smith D, Berrangé JP. Geological and geophysical evidence for a rift valley in the Guiana Shield. Geol Mijnbouw. 1969; 48(2):189-99.

Myers GS. Descriptions of new South American fresh-water fishes collected by Dr. Carl Ternetz. Bull Mus Comp Zool. 1927; 68(3):107-35.

Ramirez JL, Birindelli JLO, Galetti PM, Jr. A new genus of Anostomidae (Ostariophysi: Characiformes): diversity, phylogeny and biogeography based on cytogenetic, molecular and morphological data. Mol Phylogenet Evol. 2017; 107:308-23.

Ramirez JL, Carvalho-Costa LF, Venere PC, Carvalho DC, Troy WP, Galetti PM, Jr. Testing monophyly of the freshwater fish Leporinus (Characiformes, Anostomidae) through molecular analysis. J Fish Biol. 2016; 88(3):1204-14.

Reis RE, Kullander SO, Ferraris CJ. Check list of the freshwater fishes of South and Central America. Porto Alegre: Edipucrs; 2003.

Sabaj MH. Standard symbolic codes for institutional resource collections in herpetology and ichthyology: an Online Reference. 2016. Version 6.5 (16 August 2016). Electronically accessible at https://asih.org/sites/default/files/documents/symbolic_codes for_collections_v6.5_2016.pdf

Sidlauskas BL, Vari RP. Phylogenetic relationships within the South American fish family Anostomidae (Teleostei, Ostariophysi, Characiformes). Zool J Linn Soc. 2008; 154(1):70-210.

Taylor WR, Van Dyke GC. Revised procedures for staining and clearing small fishes and other vertebrates for bone and cartilage study. Cybium. 1985; 9(2):107-20.

Winterbottom R. Systematics, osteology and the phylogenetic relationships of fishes of the ostariophysan subfamily Anostominae (Characoidei, Anostomidae). Toronto: Royal Ontario; 1980. (Life sciences contributions, No. 123).

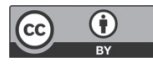

Submitted February 22, 2019

Accepted May 2, 2019 by Fernando Carvalho 